\title{
Peranan Pendidikan Islam dalam Persoalan LGBT (Lesbian,Gay, Biseksual, Transgender) di Kota Jambi
}

\author{
Muhammad Miptahuttoriq Umar ${ }^{1}$, Hamdi Bin Ishak ${ }^{2}$, \\ Muhd. Nadjib Bin Abdul Kadir ${ }^{3}$, Mohd Izwan Bin Md Yusof ${ }^{4}$, \\ ${ }^{1}$ Pelajar Fakultas Pengajian Islam Universiti Kebangsaan Malaysia \\ 2,3,4Pensyarah (dosen) Pusat Kelestarian Turath Islami Fakulti Pengajian Islam Universiti Kebangsaan Malaysia \\ Correspondence e-mail: toriq91@yahoo.com
}

\begin{abstract}
Abstrak. LGBT merupakan fenomena sosial yang sedang kita dihadapi disetiap penjuru Negara. Gerakan LGBT pada mulanya hadir pada tahun 1950an. Yang mana LGBT tersebut hadir atas dasar hak asasi manusia (HAM). Sehingga persoalan ini menjadi kekhawatiran tersendiri terhadap lapisan masyarakat, tujuan penelitian didedikasikan untuk semua kalangan dalam membina generasi yang sehat dan berakhlaq karimah, yang didasari dengan pendidikan Islam, sedangkan metode penelitian dalam kajian ini yaitu menggunakan pendekatan kualilatif. Yang mana pendekatan ini digunakan, supaya pengkaji dapat berhadapan langsung dengan para responden dan mendapatkan jawaban yang real daripada hasil wawancara bersama responden, sedangkan dalam kajian ini mendapatkan beberapa hasil yang memuaskan, bahwasanya kesemua responden jauh daripada pemahaman mahupun pengamalan dalam Islam. Sehingga mereka terlibat didalam persoalan LGBT. kesimpulan mahupun kontribusi kajian ini, yaitu membuka wawasan yang besar kepada para responden khususnya, umumnya kepada masyarakat luas, bahwasanya pendidikan Islam tidak bisa dipisahkan dalam kehidupan ini. Apapun aktivitas, dan rutinitasnya peranan pendidikan Islam (pemahaman dan pengamalan) tidak bisa dipisahkan.
\end{abstract}

Kata kunci : peranan pendidikan islam terhadap permasalahan LGBT

Abstract. $L G B T$ is a social phenomenon that we are regulating in every corner of the country. The LGBT movement was originally present in the 1950s. Which LGBT is present on the basis of human rights (HAM). This study discusses the community, research objectives for research on a healthy generation and moral behavior, which is based on Islamic education, while the research method in this study uses qualitative support. Which discusses about this is used, discussing the reviewer can connect directly with the respondents and get tangible answers from the results of interviews with respondents, while in this study get some satisfying results, that respondents were given further information about the various practices in Islam. LGBT. The conclusion of the study, which is a review of the great for special respondents, about the wider community, that Islamic education can not complement in this life. Whatever the activities, and the role of Islamic education (understanding and practice) cannot be understood

Keywords : the role of islamic education against LGBT problems

\section{PENDAHULUAN}

LGBT merupakan singkatan dari istilah Lesbian, Gay, Biseksual, Transgender (JAKIM \& YIM t.th.). permasalahan tersebut pada dasarnya bukanlah permasalahan yang baru. Akan tetapi jauh berabadabad lamanya. Sebagaimana kisahnya kaum Nabi Luth, yang mana permasalahan tersebut mengindikasikan seorang laki-laki berhubungan dengan sesama laki-laki. Hal ini dibuktikan dengan firman Allah s.w.t didalam AlQur'an yang artinya (al-Qur'an Terjemah al-Huda, 2002): "Dan (Kami juga telah mengutus) Luth (kepada kaumnya). (Ingatlah) tatkala dia berkata kepada mereka: "Mengapa kamu mengerjakan perbuatan faahisyah itu, yang belum pernah dikerjakan oleh seorangpun (di dunia ini) sebelummu? Sesungguhnya kamu mendatangi lelaki untuk melepaskan nafsumu (kepada mereka), bukan kepada wanita, malah kamu ini adalah kaum yang melampaui batas." (al-Qur'an, al-A'raf $7 ; 80$ 81).

Ayat tersebut bukti bahwa hubungan anatara lakilaki sama laki-laki telah ada berabad-abad yang lalu. Adapun pada zaman sekarang, komunitas ini lebih berani dalam menyuarakan menyuarakan aspirasinya, baik itu dalam haknya mahupun menuntut perlindungan terhadap pendapat dan perlakuannya. Hal ini dibuktikan dengan adanya perade atau aksi yang dilakukan oleh komunitas tersebut. Tepatnya pada tanggal 23 Februari 2016 di kota Yogyakarta. Yang mana Sebuah organisasi kemasyarakatan menghebohkan masyarakat
Yogyakarta. Yang mana komunitas tersebut menuntut demokrasi yang utuh untuk hak-hak dan perlindungan terhadap LGBT (Bbc Indonesia, 2016).

Jauh sebelum aksi komunitas tersebut di Yogyakarta puluhan lali-laki dan perempuan, dengan bermacam hiasa unik maupun wajar dan sebagiannya memakai jilbab. Mereka berdemonstrasi dibeberapa titik di kawasan Car Free Day, Jakarta, Minggu (17/5/2015) dengan aneka atribut pelangi, dan berakhir di Bundaran $\mathrm{HI}$ (Hotel Indonesia). Mereka sebagian orang yang melakuka aksi diseluruh penjuru dunia. Yang mana pada tanggal tersebut jatuhnya Hari Internasional Melawan Homofobia dan Transfobia. Tujuan daripada aksi tersebut, tidak lain tidak bukan, untuk menjunjung tinggi HAM (Hak Asasi Manusia). Karena mereka beranggapan ini adalah pilihan mereka untuk menjalani kehidupannya (Bbc Indonesia, 2015).

Aksi-aksi tersebut pada dasarnya menjadi kekhawatiran tersendiri bagi masyarat terkhusus di Indoesia. Sehingga tidak sedikit organisasi kemasyarakatan yang menolak aksi tersebut. Oleh karena itu pesoalan ini mesti diperhatikan oleh semua pihak terkhusus pemerintahan Indonesia.

Dalam membahasa permasalah ini, salah satu aspek yang diangkat, untuk mengetahui sejauh mana mereka terlibat dan faktor apa yang melatar belaknginya. Oleh kerana itu aspek ini akan meninjau mengenai Pendidikan Islam yang ada pada mereka. Apakah pendidikan Islam sudah tepat dalam 
membentengi seseorang dalam perbuatan LGBT? Daripada persoalan tersebut, aspek ini adalah landasan dasar dalam mempertanyakan keabsahan peranan pendidikan Islam dalam terbentuknya karakter yang baik. Sebagaimana yang kita ketahui pendidikan, terkhusus pendidikan Islam adalah modal terbesar terhadap setiap manusia. Sebagaimana kita ketahui, segala sesuatu yang kita kerjakan sekarang dan yang akan datang mestilah memiliki pertimbangan yang sangat matang. Sehingga segala sesuatu tidak terlepas daripada peranan pendidikan tersebut. Hal ini sejalan dengan apa yang difirmankan Allah s.w.t dalam alQur'an (al-Qur'an Terjemah al-Huda, 2002): "Hai orangorang beriman apabila dikatakan kepadamu: "Berlapang-lapanglah dalam majlis", maka lapangkanlah niscaya Allah akan memberi kelapangan untukmu. Dan apabila dikatakan: "Berdirilah kamu", maka berdirilah, niscaya Allah akan meninggikan orang-orang yang beriman di antaramu dan orang-orang yang diberi ilmu pengetahuan beberapa derajat. Dan Allah Maha Mengetahui apa yang kamu kerjakan." (al-Qur'an, alMujadalah $58 ; 11$ ).

Selanjutnya, ayat tersebut dipertegas lagi dengan firman Allah s.w.t, yang mana Allah s.w.t senantiasa memerintahkan kita untuk memiliki wawasan yang luas. Sebagaimana firman Allah s.w.t (al-Qur'an Terjemah alHuda, 2002): "Bacalah dengan (menyebut) nama Tuhanmu Yang menciptakan”. (al-Qur'an, al-Alaq 96 ;1).

Dua ayat diatas, bahwasanya menjelaskan kepada kita. Pendidikan, terkhusus Islam merupakan solusi utama dalam mengatasi segala permasalahan. Terkhusus permasalahan mengenai LGBT. Yang mana permasalahan ini tentunya akan menjadi kekhawatiran yang sangat besar ketika menjalar ditengah masyarakat pada umum terkhusus kepada remaja (penerus bangsa). Sehingga efek yang sangat terasa yaitu efek terhadap peradaban dan kemaslahatan dalam suatu Negara.

Daripada penjelasan diatas pengkaji akan mengkaji persoalan LGBT. Yang mana pengkaji akan menganalisis permasalahan ini ditinjau daripada aspek pendidikan Islam. Sehingga mendapatkan jawaban yang benar. Apakah pendidikan Islam salah satu solusi dalam mengatasi persoalan LGBT? Oleh karena itu, pengkaji akan mengangkat aspek tersebut. Sehingga mendapatkan jawaban yang real mengenai peranan pendidikan Islam dalam mengatasi, menyelesaikan, dan membentengi seseorang dalam perbuatan yang dilarang oleh Agama, yaitu LGBT.

\section{METODE PENELITIAN}

Dalam penilitian ini pengkaji menggunakan pendekatan kualitatif. Yang mana pendekatan kualitatif ialah metode yang menangani persoalan peristiwa masa sekarang maupun masa yang telah lalu. Apabila pendekatan ini digunakan dalam mengkaji peristiwa yang telah lau, proses tersebut dinamakan sebagai penyelidikan sejarah (history). Kemudian ketika pendekatan ini digunakan untuk membahas persoalan sekarang, kajian tersebut dikenali sebagai penyelidikan kualitatif (Gay, 1996). Kemudian ada beberapa hal yang menjadikan pengkaji berfikir ingin menggunakan pendekatan ini. Salah satu nya yang diungkapkan oleh Creswell. Bahwasanya kajian ini memiliki sifat persoalan kajian yang memerlukan jawaban kepada bagaimana dan apa yang berlaku pada persoalan masa lau dan sekarang (Creswell, 1998). Adapun tatacara ini terfokus pada merangkumi, mengumpul, menganalisis dan melaporkan data dalam kajian. Reka bentuk tersebut berlaku pada semua kajian, baik itu pendekatan kualitatif mahupun kuantitatif (Creswell, 1998 ; Mohamed, 2001). Melihat dan menimbang daripada persoalan yang hendak dibahas oleh pengkaji. Dalam kajian ini pengkaji akan menggunakan pendekatan kualitatif.

Subjek/responden dalam penelitian/kajian ini adalah orang-orang yang berdomisili di Provinsi Jambi pada umumnya, dan tentunya subjek/atau responden terlibat dalam persoalan LGBT. Kemudian ada beberaapa kriteria dalam pemilihan subjek/responden. Pertama senantiasa dalam kelompok tersebut, kedua berpakaian menyimpang (melawan kodrat). Ketiga bertubuh lentur/gemulai (terkhusus laki-laki), keempat bergaya tomboy (teruntuk perempuan). Sedangkan dalam usia, pengkaji tidak membatasi dalam perkara usia, selagi mendapatkan informasi, pengkaji terima semua kalangan terkhusus dalam hal usia.

Selanjutnya setiap responden/subjek kajian akan diberikan kode khusus. Yang mana dalam hal ini pengkaji memberikan kode dengan sebutan RS (Responden). Kemudian diberikan nomor pada setiap respnden. Dimulai dari nomor 01 hingg 03.

Sedangkan metode dalam pengumpulan data dalam kajian kualitatif pada dasarnya menggunakan metode; (a) wawancara, (b) pemerhatian, (c) bukti dokumen. Sedangkan dalam kajian ini pengkaji menggunakan tehnik wawancara dan analisis dokumen. $\mathrm{Hal}$ ini sesuai dengan kajian yang berlandaskan kualitatif. (Bogdan, R.C. \& Biklen, 2003 ; Merriam, 1998 ; Spradley, 1980).

\section{HASIL DAN PEMBAHASAN}

Pada sub bab kali ini. Pengkaji akan memaparkan dan membahas hasil dapatan kajian yang telah dilaksanakan dilapangan. Baik itu mlalui wawancara maupun analisis dokumen. Selanjutnya dalam kajian ini ada beberapa tema yang diangkat, pertama iaitu menceritakan latar belakang responden secara singkat. Kedua yaitu mengenai pemahaman ilmu agama Islam dalam terlibatnya seseorang dalam LGBT. Yang mana tema tersebut meliputi beberapa item, kebolehan dalam membaca al-Qur'an, dan yang kedua iaitu pemahaman IImu syariat (Tauhdi, Figh,Tasawuf dan lain sebagainya). Kemudian tema yang ketiga yaitu pengamalan ilmu agama Islam dalam terlibatnya seseorang dalam LGBT, meliputi pengamalan dalam membaca al-Qur'an dan yang kedua pengamalan dalam melaksanakan shalat

\section{Latar Belakang Responden Responden RS 01}

Responden yang pertama yaitu seorang laki-laki berusia tiga puluh lima (35) tahun. Yang mana laki-laki tersebut berorientasi Transgender. Dalam kesaharian beliau disibukkan dengan bermacam rutinitas. Selain itu beliau juga senantiasa berbaur dengan orang-orang dilingkungan rumah maupun dilingkungan aktifitas beliau. 


\section{Responden RS 02}

Responden yang kedua yaitu seorang laki-laki berusia tiga puluh lima (30) tahun. Yang mana RS 02 ini berorientasi Gay dalam seksualnya. Dalam kesaharian, beliau disibukkan dengan berbagai pekerjaan. Ditinjau daripa kesosialannya ditengah masyarakat beliau orang yang ramah dan senang berbaur dengan orang-orang dilingkungan rumah maupun lingkungan tempat beliau bekerja.

\section{Responden RS 03}

Responden yang ketiga yaitu seorang perempuan berusia 26 tahun. Beliau seorang mahisiswi diperguruan tinggi ternama di Indonesia. Yang mana orientasi seksualnya yaitu lesbian. dalam beberapa kali pertemuan dengan beliau. Beliau termasuk orang yang sangat ramah dan terbuka dalam memberikan informasi.

\section{Pemahaman IImu Agama Islam Dalam Terlibatnya Seseorang Dalam LGBT}

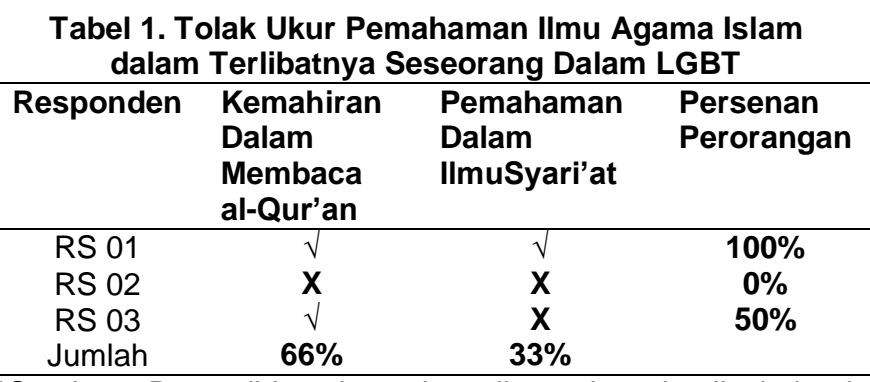

*Sumber: Data didapatkan dan dipaparkan hasil daripada wawancara dengan responden dilapangan.

\section{Kemahiran dalam membaca al-Qur'an}

Item ini akan membahasa mengenai kemahiran dalam membaca al-Qur'an. Yang mana RS 01 memberikan pernyataan:

\begin{abstract}
"Saya akui sudah lama saya tidak mebaca al-Qur'an. Kerana kegiatan yang sangat padat, ditambah lagi dalam pergaulan saya sedikit sekali orang yang membaca al-Qur'an. Kalau dalam mebaca sedikit banyak saya tahu, walaupun tidak begitu mahir. Akan tetapi saya dulu pernah mengayam pendidikan alQur'an di masa dini dan remaja." (Miptahuttoriq, 2018)
\end{abstract}

Selanjutnya dipertegas dengan penjelasan RS 03:

"Saya akui, saya hanya sedikit bisa dalam membaca al-Qur'an. Terus terang sudah lama sekali saya tidak mengaji. Sewaktu kecil, saya hafal beberapa ayat bahkan beberapa surah dalam al-Qur'an. Seperti surah Yāsin dan lain sebagainya. Dan rasanya rugi ketika tidak membaca al-Qur'an. Apalagi sekarang sudah jauh sekali daripada al-Qur'an. Perkara inilah yang membuat saya lupa akan sang khaliq". (Miptahuttoriq, 2018)

Walaupun demikian, daripada tiga responden, ada satu responden yang tidak bias membaca al-Qur'an, yaitu responden RS 02 . Ini dibuktikan dengan pernyataannya:
"Saya jujur tidak bisa membaca al-Qur'an, sudah lama sekali saya tidak belajar al-Qur'an. Sebabnya saya kurang cepat tanggap dalam membaca alQur'an. Walaupun begitu ada rasa menyesal terhadap diri saya, kenapa saya tidak giat dalam mempelajari al-Qur'an, padahal ini suatu keharusan bagi orang Islam". Oleh demikian itulah, saya tidak pernah membaca al-Qur'an." (Miptahuttoriq, 2018)

Kemahiran dalam membaca al-Qur'an sangatlah penting dalam kehidupan (terkhusus responden), ketika mereka mahir dalam membaca al-Qur'an, maka mereka senantiasa mengambil satu waktu untuk membacanya. Apalagi ketika mereka sudah merasa nyaman dalam melafazkan ayat-ayat al-Qur'an. Tentunya akan berimpak positif bagi mereka.

Pada dasarnya ketika Item ini tidak terealisasikan didalam kehidupan, maka akan menjadi penghalang mereka dalam menggali isi kandungan al-Qur'an yang mana pada dasarnya banyak peringatan bagi mereka yang senantiasa melakukan perbuatan LGBT tersebut. Bahkan rasulullah memberikan pernyataan, untuk menggairahkan seseorang dalam mempelajari alQur'an. Sebagaimana hadith Nabi Muhammad s.a.w:

Artinya: "Siapa yang membaca satu huruf dari Al Quran maka baginya satu kebaikan dengan bacaan tersebut, satu kebaikan akan dilipatkan gandakan menjadi 10 kebaikan semisalnya dan aku tidak mengatakan الم satu huruf akan tetapi Alif satu huruf, Laam satu huruf dan juga Miim satu huruf." (HR. Tirmidzi)

\section{Pemahaman Dalam IImu Syari'at}

Sedangkan item yang kedua yaitu pemahaman mereka dalam IImu syariat. Yang mana terdapat beberapa responden yang tidak paham sama sekali dengan ilmu syariat (Islam). Ini dibuktikan dengan pernyataan Responden RS 02:

"terus terang, saya jauh akan pemahaman dalam
ilmu syari'at. Apalagi dilingkungan dunia saya jauh
dari kata-kata agama. Sehingga pemahaman saya
tidak berkembang. Walaupun demikian saya tidak
malu bertanya kepada orang yang tau akan ilmu
syari'at." (TW RSO2 H.4)

Selanjutnya dipertegas dengan pernyataan Responden RS 03:

"Soal pemahaman saya akan ilmu syari'at. Sangtlah jauh dari kata paham. Karena saya emang tidak pernah mendalami ilmu syaria't. kalau sebatas tau, saya dulu sewaktu sekolah SD pernah belajar sebatas peraktek ibadah, itu saja tidak lebih". (Miptahuttoriq, 2018)

Walaupun demikian, ternyata ada satu responden yang sangat paham akan ilmu syariat. Ini dibuktikan dengan pernyataan Responden RS 01:

"Pemahaman dalam ilmu syari'at saya pada dasarnya sama seperti orang kebanyakan, karena saya senantiasa mengikuti beberapa pengajian. Jadi 
sedikit banyak saya tau akan ilmu syariat" (Miptahuttoriq, 2018)

Sebagaimana hasil perbincangan diatas, terdapat dua orang responden dari tiga responden yang sama sekali tidak paham akan ilmu syariat, padahal apapun pekerjaan, provesi, aktivitas, mendalami atau memahami ilmu syariat sangatlah diutamakan, untuk membentengi perkara-perkara yang mempengaruhi kita dalam perilaku menyimpang.

\section{Pengamalan IImu Agama Islam Dalam Terlibatnya Seseorang Dalam LGBT.}

Tabel 2. Tolak Ukur Pengamalan Ilmu Agama Islam dalam Terlibatnya Seseorang Dalam LGBT

\begin{tabular}{cccc} 
Responden & $\begin{array}{l}\text { Pengamalan } \\
\text { Dalam } \\
\text { Membaca al- } \\
\text { Qur'an }\end{array}$ & $\begin{array}{l}\text { Pengamalan } \\
\text { Dalam } \\
\text { Melaksanakan } \\
\text { Shalat }\end{array}$ & $\begin{array}{l}\text { Persenan } \\
\text { Perorangan }\end{array}$ \\
\hline RS 01 & $\mathbf{X}$ & $\mathbf{X}$ & $\mathbf{0} \%$ \\
RS 02 & $\mathbf{X}$ & $\mathbf{X}$ & $\mathbf{0 \%}$ \\
RS 03 & $\mathbf{X}$ & $\mathbf{X}$ & $\mathbf{0 \%}$ \\
Persen & $\mathbf{0} \%$ & $\mathbf{0 \%}$ & \\
\hline
\end{tabular}

\section{Pengamalan Dalam Membaca Al-Qur'an}

Item yang pertama dari tema pengamalan ilmu agama islam dalam terlibatnya seseorang dalam LGBT yaitu pengamalan dalam membaca al-Qur'an. Sebagaimana kita ketahui al-Qur'an adalah pedoman bagi seluruh manusia (terutama orang Islam). Yang mana ketika seseorang membacanya, amakan akan berimpak positif bagi mereka. Oleh kerana itu apakah item ini dikerjakan oleh responden atau tidak sama sekali? Pernyataan daripada responden sangat membantu dalam menjawab persoalan ini. Ini dibuktikan dengan pernyataan responden RS 01 :

"Sangat setuju kalau kita membaca al-Qur'an akan berimpak positif pada jiwa kita. Kerana jelas itu kalam yang sakral. Akan tetapi saya boleh dikatakan lama tidak membaca al-Qur'an" (Miptahuttoriq, 2018)

Selanjutnya dikuatkan lagi dengan pernyataan responden RS 02:

"pada dasarnya jawaban saya sama seperti diatas. Saya tidak bisa membaca al-Qur'an, apalagi saya memahami dan mengamalkannya. Walaupun demikian saya yakin, inilah faktor terlibatnya saya dalam perbuatan ini". (Miptahuttoriq, 2018)

Kemudian dipertegas dengan pernyataan responden RS 03:

"Saya sangat setuju kalau membaca al-Qur'an memberikan manfaat. Baik itu secara zahir mahupun batin. Akan tetapi saya benar-benar sudah lama tidak membaca al-Qur'an apalagi mendalami isi kandungan al-Qur'an." (TW RS03 H.6)

\section{Pengamalan Dalam Melaksanakan Shalat}

Item yang kedua yaitu mengenai pengamalan dalam melaksanakan shala. Bahwasanya item ini menjadi tolak ukur ketaatan seseorang terhadap sang khaliq. Sebagaimana firman Allah s.w.t(al-Qur'an Terjemah al-Huda, 2002):

Artinya: "Sesungguhnya shalat itu mencegah dari perbuatan keji dan munkar” (al-ankabur $29: 45$ )

Ayat tersebut sangat jelas menjelaskan shalat adalah ibadah yang mampu mencega perbuatan yang munkar. Oleh kerana itu pernyataan dari para responden sangat dinanti dalam item ini. Sebagaimana hasil wawancara, bahwasanya responden RS 02 memberikan pernyataan sebagai berikut:

"Dalam hati yang paling dalam shalat dan kewajipan yang diperintahkan Agama akan dapat membantu saya dalam persoalan ini. Permasalahannya saya bukan orang faham dan tekun dalam ibadah" (Miptahuttoriq, 2018)

Kemudian diperjelas dengan pernyataan responden RS 03:

"Pada dasarnya saya setuju, kalau shala itu dapat berimpak positif bagi saya. Permasalahannya saya jarang melaksanakan shalat. Mungkin ini yang membawa saya melakukan perbuatan yang menyimpang, disebabkan jauh akan ibadah kepada Allah S.W.T". (Miptahuttoriq, 2018)

Walaupun demikian responden RS 01, memberikan argument yang berbeda daripada responden lainnya. Ini dibuktikan dengan pernyataannya:

"Melaksanakan kewajiban, dan rutinitas keagamaan lainnya, hanya sebatas untuk mengawal diri. Kalau untuk menghilangkan itu sangat sulit. Sejujurnya saya sudah jarang dalam mengerjakan shalat." (Miptahuttoriq, 2018)

Pada dasarnya kesemua responden tidak taat dalam mengalankan perintah agama (shalat). Dengan bermcam-macam alasan. Menurut hemat pemikiran pengkaji faktor ini sangat kuat terhadap melibatkan responden dalam perilaku LGBT.

\section{SIMPULAN}

Persoalan LGBT pada dasarnya bisa diselesaikan dengan bertumbuhnya pengetahuan dan penerapan dalam pengamalan dalam Agama. Dengan bertambahnya ilmu Agama kita dapat mengetahui mana yang baik dan mana yang tidak baik. Selain itu didalam ilmu Agama terdapat dalil-dalil yang memberikan peringatan, larangan, ancaman, dan tentunya nasehat kepada orang yang berbuat demikian.

Sebagaimana hasil daripada kajian ini, terdapat cela yang menjadikan para responden terlibat dalam LGBT. Yaitu kurangnya pemahaman dan pengamalan terhadap pendidikan Islam.

Dari sinilah pentingnya akan peranan pengetahuan Agama. Supaya mendapatkan informasi yang benar dan mendapatkan ketenangan jiwa dalam kehidupan. Sehingga problematika yang mereka hadapi dapat diselesaikan dengan luasnya pengetahuan 
Agama. Begitu juga sebaliknya ketika minimnya seseorang akan ilmu Agama maka berdampak kepada moral seseorang. Sebagaimana permasalahan LGBT.

Daripada perbincangan diatas pengkaji memberikan beberapa saran terhadap lapisan masyarakat terkhusus kepada pemerintah pada saat sekarang:

1. Mengatur perundang-undangan yang jelas terhadap persoalan LGBT.

2. Pendidikan mengenai Agama harus ditingkatkan dalam setiap lembaga pendidikan.

3. Norma-norma Agama mesti diterapkan dalam keseharian.

4. Remaja mesti aktif dalam aktivitas yang positif.

Pengkaji berharap besar tehadap hasil daripada perbincangan dalam persoalan LGBT mendapatkan titik temu terhadap peranan pendidikan Islam dalam mengatasi persoalan tersebut. Sehingga kajian ini bermafat bagi seluruh masyarakat pada umumnya.

\section{DAFTAR PUSTAKA}

al-Qur'an Terjemah al-Huda (2002). Depok: al-Huda.

$\mathrm{Bbc}$ Indonesia (2015) Menuntut Hak. http://www.bbc.com/indonesia/majalah/2015/05/15 0517_idahot_2015.

Bbc Indonesia (2016) Demonstrasi Lgbt. http://www.bbc.com/indonesia/berita_indonesia/20 16/02/160223_indonesia_demonstrasi_lgbt.

Bogdan, R.C. \& Biklen, S. K. (2003) Qualitative research for education. An introduction to teories and methods. Unted State of America: Group Inc.

Creswell, J. . (1998) Qualitative inquiry and research design, choosing among five traditions. California: SAGE Publications.

Gay, L. . (1996) Educational Research Competencies for Analysis and Application. New Jersey: PrenticeHall Inc.

JAKIM \& YIM (no date) 'Memahami Lesbian, Gay, Biseksual, Transgender (LGBT) Dari Perspektif Seorang Muslim, Jabatan Kemajuan Islam Malaysia (Jakim) dan Yayasan Ihtimam Malaysia (Yim)'.

Merriam, S. . (1998) Qualitative research and case study applications in education. SanFrancisco: JosseyBass.

Miptahuttoriq, M. (2018) Transkip Wawancara LGBT. jambi.

Mohamed Othman (2001) Penulisan Tesis Dalam Bidang Sains Social Terapan. Serdang: Universiti Putra Malaysia.

Spradley, J. P. (1980) Participant observation. New York: Holt, Rinehart \& Winston. 